\title{
The Science Knowledge Competence Process Base of New Learners in the Biology Subject
}

\author{
Baiq Fatmawati, ${ }^{1, *}$

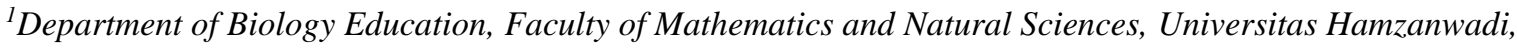 \\ Indonesia \\ *Corresponding author. Email: baiq.fatmawati@hamzanwadi.ac.id
}

\begin{abstract}
Competences Process were the all directed Science Knowledge Competence which was used to get definition, fundamental, or idea to enhance pre-existing definitions. Knowledge Competence Process included perceptive, guide, and social competence. As for basic Competence Process were observing, classifying, evaluating, communicating, predicting and inferring. Focus of the research is to gain the main competence process of new students in biology subject. The respondents were all students of biology education department in the first semester. The research instrument was a student worksheet with the topic given "life in the biosphere". The data analysis used was descriptive statistics by calculating score of the basic process skills result then classified them into high, medium, and low categories. Generally, for all categories was high (0\%), medium (25\%), and low (75\%), the score for each indicator basic science process skills was also calculated through observation, communication, classification, prediction, and inference. Therefore, the leaners were still not able to do the classification indicators because they were confused with the meaning of grouping.
\end{abstract}

Keywords: Science knowledge competence process, New students, Biology subject

\section{INTRODUCTION}

The goals of a lesson are to provide knowledge, enlarge the knowledge of learning materials, and instill scientific attitudes that ultimately shape students' character, train skills in the form of soft skills and hard skills to equip them to solve life problems. The knowledge gained can go through any process as long as it is interesting and it is important solution to solve problems, especially most problems faced in the globalization era that require various kinds of skills as expressed by [1] namely digital skills, inventive thinking skills, and effective communication skills.

The teacher is one of the main factors in clarifying the deliveries of learning content; the delivery can be through certain methods and techniques to facilitate understanding and acceptance of the material. [2] expressed their idea in the teaching and learning process, teachers must be able to deliver good material instead in essence teaching is a way of sharing new experience, competence, and behaviors in a person as a point of their interactions with kinds evidence and the surrounding. [3] suggest that learning requires teachers who were able to help students in comprehending and knowing scientific knowledge, scientific discussion, conceptual point construction, skill enhance and increasing overcoming the problems. Therefore, teachers must be able to convey material through good pedagogical activities. However, the reality happened in the learning process is the teacher still delivered material through direct instruction, discussion, assignments, and any more teachers did not focus on students' scientific thinking skills. As the opinion of [4] usually teachers give assignments directly from textbooks, worksheets or work on worksheets with the task of summarizing the material as a way for students to be more active.

Hamzanwadi University of new biology leaners come from various majors in high school, such as Science, Social Sciences, and Technology. Even though they come from science, some of them were still confused about how to solve a problem scientifically. Because the techniques used by their teachers still used a learning system that assesses the cognitive level of $\mathrm{C} 1$ and $\mathrm{C} 2$, namely remembering and understanding, and C6 students looked confused to finish it, it seemed that students were not trained enough to think scientifically and think at High level 
students. The same thing was stated by [5], the students' perceptive level is still at the comprehending and science knowledge level, lest the applicant terminology, analyzing, synthesizing, and measuring. It occurs because higher education system of learning was more mostly lecturing method different from competence process. Whereas skills to solve problems scientifically were very important to be mastered.

General biology course is one of the courses that can be used to provide an understanding of how to think scientifically as well as higher-order thinking and it's one of major subjects in the biology Education Curriculum, [6] state that in order to become Scientific's literacy citizens, teacher assert teaching methods which are effective among them. Moreover, learners must get, verify, and then investigate a problem because that is one way to use a scientific approach [7]. Suggested by [8] in preparing candidates of science teacher to include pedagogical content knowledge courses that will focus on science materials process and skills. Moreover, if they have understood the scientific method, scientific thinking, and higherorder thinking, they have become terms to describe these scientific skills process. [9] also argues that in preparing to become an innovative teacher to convey knowledge which have learners' target, reliable new recruit are needed.

Process skills can be used in any field of science, [10] suggests that process skills need to be identified and discussed as skills that can be implemented in many subjects. Because the field of biology was the competence process known as Science Knowledge Competence. Science Knowledge Competence were competence of thinking used by someone to construct their experiences in solving case encountered. Science Knowledge Competence were skills applied in the scientific field. The previous research on Science Knowledge Competence were conducted a lot but by suggesting different Science Knowledge Competence indicators such as [11] the observed Science Knowledge Competence aspects were observation, concluding, measuring, prediction, communication, classifying. [12], Science Knowledge Competence observed of this research was by observation, classification, communication, prediction, and inference.

Relating to the indicators of Science Knowledge Competence descriptions, the indicators of Science Knowledge Competence examined were Science Knowledge Competence Base which involved observing, communicating, classifying, predicting, and inferencing, those indicators refer to the theory of [13] namely Science Knowledge Competence Base involved observing, communicating, classifying, predicting, and inferencing, measuring skills. The aims of the research was to know the new learners' competence of Hamzanwadi University biology education in terms of Science Knowledge Competence Base which involved observing, communicating, classifying, predicting, and inferencing.

\section{METHOD}

The study was a descriptive field that determined the Science Knowledge Competence Process Base of New Learners in the Biology Subject. The Participants were 24 learners. The collecting data was learners' worksheets with indicators of the Science Knowledge Competence Base which involved observing, communicating, classifying, predicting, and inferencing (attached) and it was analyzed descriptively quantitatively by calculating gain then percentage as conducted by [14]. The results of these percentages were categorized into low, medium, and high categories Base on the formula used by Hake [15].

\section{RESULT AND DISCUSSION}

Assessing learners' Science Knowledge Competence Process Base was point of biology subject because most of the learners were active [16]. Through a general biology course on ecosystem material with the theme "life in the biosphere", researchers try to see this in biology education new students in answering questions to find out their basic process skills, see the bellow figures.

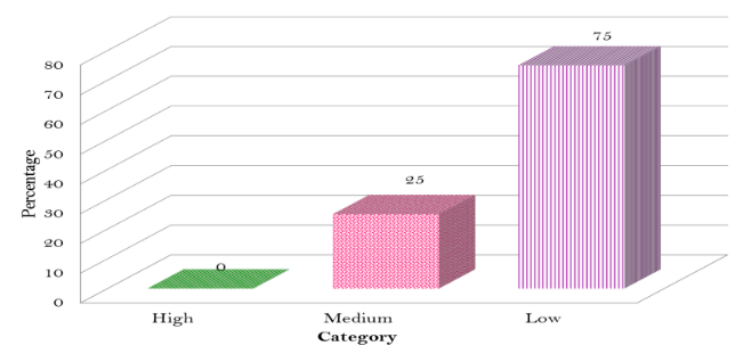

Figure 1 The category of the science knowledge competence base on new biology learners

The figure 1 shows that new learners had low category basic science process skills; it was $75 \%$ as well as the figure 2. It shows that each new learner got a different percentage, only the inference indicator showed a high category, it was $83 \%$. The other indicators were included in the low category; the lowest was the classification indicator. On this indicator, after correcting the learners' answer, the 
answer was to classify even though the request is to classify. Based on these results, the researcher tried to interview learners. Factually, they were confused with the term, the same interpreting between classification and grouping. So, this proved that new biology learners were not used to express their basic science process skills. [17] \& [18] also found the same thing in students who were taught with these science process skills, the scores for all indicators science process skill were low category.

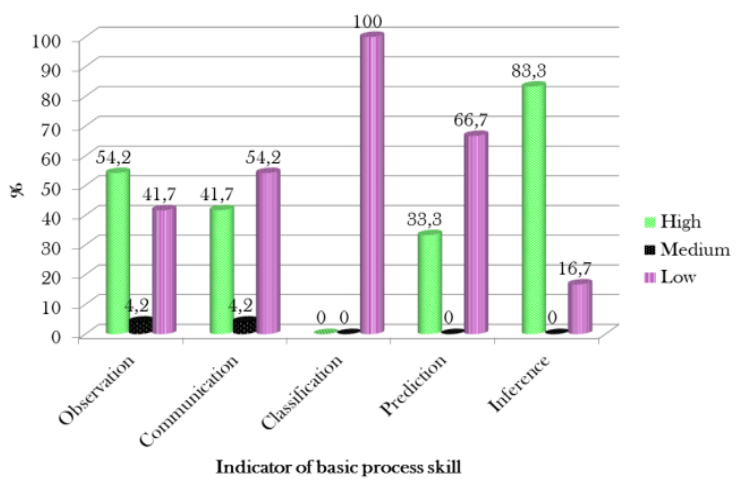

Figure 2 The category of the science knowledge competence base with indicator achievement on new learners

As previously stated, students at school were not accustomed to thinking scientifically so they had difficulty to answer the questions related to the higher order thinking. Because usually teachers touch material conceptually and rarely touch scientific thinking. Moreover, teachers found it difficult to reproduce questions that lead to thinking skills and scientific processing. Meanwhile, the second part covers scientific thinking, critical thinking, and scientific process. However, teachers evaluated more the first part and ignored the second part because they felt the teaching of thinking skills and scientific processes was a waste of time and effort. Whereas in science learning, thinking skills and scientific processes were the basic knowledge that students must mastered.

A new paradigm in educational reform is preparing through innovative pedagogical strategies, one of strategy for practicing scientific thinking habits is to use process skills. For students who have never been familiar with process skills, it is advisable for teachers to use the basic process skills namely observation, classification, measurement, communication, prediction, and inference. Because by using these basic process skills, students will think and behave scientifically in solving problems. Teachers must be more proficient in understanding these process skills therefore the students acquire the skills needed through practical science [19]. Biology education students as future teacher candidates who will teach their students must master these basic process skills before because teachers are a domain in transferring knowledge. It is also suggested by some researchers to conduct research on process skills to be a higher level so the results are more satisfying [20] \& [21].

Researchers have conducted various ways to conduct research on these process skills, some are integrating them with other techniques in the aim at improving the quality of learning, such as [22] which examines effect of Project-Oriented Learning on Science Knowledge Competence Process Base and teacher Self-Efficacy of new teacher in the aim at improving quality of education, motivating, and increasing self-efficacy, increasing skill mastery, enriching experiences, and spurring new enthusiasm for prospective teachers. It is also hoped that the next researchers will conduct research on these science process skills on other suitable materials to think scientifically and know science process skills that will be applied to other content biology and habituate students to higher thinking, especially for new student who have never had learning experiences that train thinking skills Base of Higher Order Thinking skills (HOTs).

\section{CONCLUSION}

Teaching Science Knowledge Competence Process Base not only serves a basis method for scientifically otherwise a valuable opportunity to learn learning Science subject. Therefore, the students did not get low scores $(75 \%)$ as done of this research, the teachers needs to use methods or techniques in teaching biology because effective teaching related to the methods or techniques used the teacher in the teaching and learning, and the teacher acts as a facilitator in learning such as guiding and directing students. Additionally, using science process skills, the teacher also needs to explain each indicator of the basic process skills meanwhile there is no misunderstanding of meaning such as classification and grouping.

\section{REFERENCES}

[1] P. Turiman, J. Omar, A.M. Daud, K. Osman, Ostering the 2st century skills through scientific literacy and science process skills, in: ProcediaSocial and Behavioral Science, vol. 59, Elsevier, Amsterdam, 2012, pp. 110-116. DOI: https://doi.org/10.1016/j.sbspro.2012.09.253 
[2] J. Juhji, P. Nuangchalerm, Interaction Between Scientific Attitudes and Science Process Skills toward Technological Pedagogical Content Knowledge, Journal for the Education of Gifted Young Scientists 8(1) (2020) 1-16. DOI: http://dx.doi.org/10.17478/jegys.60079.XX

[3] M. Duran, İ. Dökme, The Effect of The InquiryBased Learning Approach on Student's CriticalThinking Skills, Eurasia Journal of Mathematics, Science \& Technology Education 12(12) (2016) 2887-2908.

DOI: https://doi.org/10.12973/eurasia.2016.02311a

[4] S. Wahyuni, Indrawati, Sudarti, W. Suana, Developing Science Process Skills and Problem Solving Abilities Base on Outdoor Learning in Junior High School, Jurnal Pendidikan IPA Indonesia 6(1) (2017) 165-169. DOI: https://doi.org/10.15294/jpii.v6i1.6849

[5] A. Hadis, Nurhayati, Developing science process skill based learning in science for children with special needs course, in: Journal of Physics: Conference Series, vol. 1028, IOP Publishing, Bristol, 2018, pp. 1-6. DOI: https://doi.org/10.1088/1742$\underline{6596 / 1028 / 1 / 012210}$

[6] S. Hebert, S. Cotner, A Comparison of Nonmajors' \& Majors' Incoming Science Process Skills, The American Biology Teacher 81(8) (2019) 554-560. DOI: https://doi.org/10.1525/abt.2019.81.8.554

[7] M. Hodosyová, J. Útla, M. Vanyová, P. Vnuková, V. Lapitková, The development of science process skills in physics education, in: ProcediaSocial and Behavioral Sciences, vol. 186, Elsevier, Amsterdam, 2015, pp. 982-989. DOI: https://doi.org/10.1016/j.sbspro.2015.04.184

[8] N. Kruea-In, O. Thongperm, Teaching of science process skills in thai contexts: Status, supports and obstacles, in: Procedia-Social and Behavioral Sciences, vol. 141, Elsevier, Amsterdam, 2014, pp. 1324-1329. DOI: https://doi.org/10.1016/j.sbspro.2014.05.228

[9] M. Çalık, Effect of Technology-Embedded Scientific Inquiry on Senior Science Student Teachers' Selfefficacy, Eurasia Journal of Mathematics, Science \& Technology Education 9(3) (2013) 223-232 DOI: https://doi.org/10.12973/eurasia.2013.931a
[10] S. Yamtinah, M. Masykuri, Ashadi, A.S. Shidiq, An analysis of students' science process skills in hydrolysis subject matter, using testlet instrument, in: Advances in Social Science, Education and Humanities Research (ASSEHR), vol. 158, Atlantis Press, Amsterdam, 2018, pp. 101-110. DOI: https://dx.doi.org/10.2991/ictte$\underline{17.2017 .36}$

[11] R.A.A. Rauf, M.S. Rasul, A.N. Mansor, Z. Othman, N. Lyndon, Inculcation of Science Process Skills in A Science Classroom, Asian Social Science 9(8) (2013) 47-57. DOI: https://doi.org/10.5539/ass.v9n8p47

[12] P. Siahaan, A. Suryani, I. Kaniawati, E. Suhendi, A. Samsudin, Improving students' science process skills through simple computer simulations on linear motion conceptions, in: Journal of Physics: Conference Series, vol. 812, IOP Publishing, Bristol, 2017, pp. 1-6. DOI: https://doi.org/10.1088/1742-6596/812/1/012017

[13] P. Rowland, C.L. Stuessy, L. Vick, Basic Science Process Skills An Inservice Workshop Kit: Workshop Manual, New Mexico State University., 1987.

[14] R. Susanti, Y. Anwar, Ermayanti, Profile of science process skills of preservice biology teacher in general biology course, in: Journal of Physics: Conference Series, vol. 1006, IOP Publishing, Bristol, 2018, pp. 1-6. DOI: https://doi.org/10.1088/1742$\underline{6596 / 1006 / 1 / 012003}$

[15] A. Savinem, P. Scott, The Force Concept Inventory: A Tool for Monitoring Student Learning, Physics Education 37(1) (2002) 42-45. DOI: https://doi.org/10.1088/00319120/37/1/306

[16] E.S. Safaah, M. Muslim, W. Liliawati, Teaching science process skills by using the 5-stage learning cycle in junior high school, in: Journal of Physics: Conference Series, vol. 895, IOP Publishing, Bristol, 2017, pp. 1-6. DOI: https://doi.org/10.1088/1742-6596/895/1/012106

[17] Sunyono, Science Process Skills Characteristics of Junior High School Students in Lampung., European Scientific Journal 14(10) (2018) 32-45. DOI: http://dx.doi.org/10.19044/esj.2018.v14n10p32

[18] B. Fatmawati, Science process skills of eigthgrade students at SMPN 2 Masbagik, in: 
Advances in Social Science, Education and Humanities Research, vol. 432, Atlantis Press, Amsterdam, 2020, pp. 75-77. DOI: https://doi.org/10.2991/assehr.k.200417.017

[19] N. Kruea-In, O. Thongperm, Teaching of science process skills in thai contexts: status, supports and obstacles, in: Procedia-Social and Behavioral Sciences, vol. 141, Elsevier, Amsterdam, 2014, pp. 1324-1329. DOI: https://doi.org/10.1016/j.sbspro.2014.05.228

[20] R. Chebii, S. Wachanga, J. Kiboss, Effects of Science Process Skills Mastery Learning Approach on Students' Acquisition of Selected Chemistry Practical Skills in School, Creative Education 3(8) (2012) 1291-1296. DOI: http://dx.doi.org/10.4236/ce.2012.38188

[21] B. Aydogdu. The Investigation of Science Process Skills of Science Teachers in Term of Some Variables, Educational Research and Review 10(5) (2015) 582-594. DOI: https://doi.org/10.5897/ERR2015

[22] D. Hernawati, M. Amin, M. Irawati, S. Indriwati, M. Aziz, Integration of Project Activity To Enhance The Scientific Process Skill and SelfEfficacy in Zoology of Vertebrate Teaching and Learning, Journal of Mathematics, Science and Technology Education 14(6) (2018) 2475-2485. DOI: https://doi.org/10.29333/ejmste/89940 